\title{
Allergen immunotherapy for the treatment of allergic rhinitis and/or asthma: an umbrella review
}

\author{
Jesse Elliott MSc, Shannon E. Kelly MSc, Amy Johnston MSc, Becky Skidmore MLS, Tara Gomes MHSc,
} George A. Wells PhD

\section{Abstract}

Background: Allergic rhinitis and asthma are important public health concerns, yet there is no consensus about the benefits and harms of allergen-specific immunotherapy to treat these conditions. We performed an umbrella review of systematic reviews summarizing the current evidence for the benefits and harms of subcutaneous immunotherapy (SCIT) and sublingual immunotherapy (SLIT).

Methods: We searched MEDLINE, Embase, the Cochrane Library and the grey literature from Jan. 1, 2010 to Nov. 20, 2016 for systematic reviews of randomized controlled trials or prospectively controlled studies involving children or adults with allergic rhinitis or asthma. Outcomes were summarized narratively (benefits: total combined symptom-medication score, symptom score, medication score, disease-specific quality of life, adherence; harms: anaphylaxis, death, local and systemic reactions).

Results: Twenty-three systematic reviews were included. SCIT and SLIT were more effective than placebo for most outcomes. SCIT was better than SLIT at improving medication and symptom scores, with no differences in quality of life; however, data were limited for this comparison. Anaphylaxis and death were infrequently reported. Few reviews assessed benefits or harms among children.

Interpretation: Allergen immunotherapy appears to be effective among patients with allergic rhinitis and asthma. The safety of allergen immunotherapy is not conclusively established, although death and anaphylaxis appear to be rare. PROSPERO no.: CRD42015024590

\footnotetext{
$\checkmark$ easonal and perennial allergic rhinitis and allergic asthma represent important public health concerns, affecting up to $30 \%$ of adults ${ }^{1}$ and $40 \%$ of children. ${ }^{2}$ These conditions lead to reduced quality of life, attendance and productivity at work or school, quality of sleep and involvement in outdoor activities. ${ }^{3}$ Current clinical practice guidelines recommend that patients who have an inadequate response to or adverse events following pharmacologic interventions be referred for immunotherapy. ${ }^{3}$ Allergen-specific immunotherapy may consist of subcutaneous (SCIT) or sublingual (SLIT) immunotherapy and may have persistent benefits after treatment is stopped. ${ }^{4}$ SCIT, considered the gold standard, involves the injection of extracts to which the patient is allergic, which increases the risk of local and systemic reactions, necessitating injection in a hospital or medical facility. ${ }^{5}$ As an alternative, SLIT may have a reduced risk of local or systemic reactions and may be administered at home..$^{5}$ A recent international consensus statement suggested that allergen immunotherapy is underused because of, in part, a lack of agreement about efficacy. ${ }^{6}$
}

The Ontario Drug Policy Research Network has developed a novel program to review multiple drugs from a single class as part of a formulary modernization process. The network's approach to these drug class reviews involves using multiple research methods in an expedited timeline $(6 \mathrm{mo})$ to evaluate the effectiveness, safety and accessibility of multiple agents within a single drug class. To inform health care decision-makers in Ontario, a review of allergen immunotherapy was begun in May 2015. During the review period, multiple research teams completed 5 research projects on the topic,

Competing interests: Becky Skidmore is a paid information consultant/ contractor to the University of Ottawa Heart Institute. No other competing interests were declared.

This article has been peer reviewed.

Correspondence to: George A. Wells, gawells@ottawaheart.ca CMAJ Open 2017. DOI:10.9778/cmajo.20160066 
including an environmental scan, a pharmacoepidemiologic study, a qualitative study, a pharmacoeconomic review and an umbrella review of comparative benefits and harms (reported here). Umbrella reviews are an ideal method to rapidly synthesize existing systematic reviews and/or meta-analyses and to comprehensively review the literature in a rapid manner. ${ }^{7}$

Thus, to inform policy recommendations on the use of immunotherapy in Ontario, we performed a rapid umbrella review of existing systematic reviews that assessed the benefits and harms of allergen immunotherapy for treatment of allergic rhinitis or asthma.

\section{Methods}

We used systematic methods and followed the methodology guidelines for umbrella reviews provided by the Joanna Briggs Institute ${ }^{7}$ throughout to limit bias and to ensure a transparent and comprehensive review. The protocol was registered before the literature search (PROSPERO no. CRD42015024590).

\section{Rapid review}

Rapid review is an approach used to expedite evidence synthesis. It generally take less time to complete than a systematic review. ${ }^{8}$ A variety of approaches may be used to tailor traditional systematic review methods with the aim of meeting the requirements and timelines of a health care decisionmaker. Rapid review authors generally aim to use the most rigorous methods that the review time frame will allow for. A variety of approaches may be employed to accelerate the evidence synthesis process, including limiting the type or number of research questions, restricting the literature search or types of studies included, or reducing the number of variables extracted and/or synthesized.

\section{Search strategy}

We identified systematic reviews of allergen immunotherapy from Ovid MEDLINE, Ovid MEDLINE In-Process \& Other Non-Indexed Citations, Embase and the Cochrane Library (Database of Systematic Reviews, Database of Abstracts of Reviews of Effects, Health Technology Assessment Database). We searched the grey literature using Grey Matters Light. ${ }^{9}$ The search strategies (Appendix 1, available at www.cmajopen.ca/content/5/2/E373/suppl/DC1) used a combination of controlled vocabulary and keywords and were adjusted across databases. Because our aim was to perform a rapid review of current evidence, the search was date limited (2010 to May 31, 2015), and we summarized the findings from reviews available in English. We used a sensitive systematic review/meta-analysis filter to focus the results. The search was updated Nov. 20, 2016 to capture the most recently published reviews.

\section{Study selection}

We included systematic reviews that included randomized controlled trials or prospectively controlled primary study designs. Interventions of interest were SLIT (single or multi- ple allergen) or SCIT. Comparators could be placebo, usual care or active control.

Systematic reviews, health technology assessments, indirect treatment comparisons, network meta-analyses or metaanalyses were eligible for inclusion. We considered evidence syntheses to be systematic if a defined search strategy was provided, 2 or more databases were searched and explicit eligibility criteria were reported. For benefits (total combined symptom-medication score, symptom score, medication score, disease-specific quality of life, adherence), syntheses must have included randomized controlled trials. Both randomized controlled trials and prospective controlled primary studies were eligible for harm outcomes (local or systemic reactions, anaphylaxis, death).

We excluded reviews that included nonallergic or occupational rhinitis, rhinitis caused by hormones/hypothyroidism, medication, or atrophic mucosa or other inflammatory/immunologic disorders, and rhinitis in pregnancy; reviews that included nonallergic asthma; nonsystematic reviews; broader reviews that did not report relevant subanalyses; and reviews of reviews.

\section{Data extraction and quality assessment}

Two reviewers (J.E., A.J.) screened each title and abstract, and the full text of any potentially relevant record. Disagreements were resolved by consensus with a third author (S.K.). Studies were not excluded on the basis of reported outcomes. Data were extracted by 1 reviewer using piloted abstraction forms and verified by a second reviewer (J.E., A.J.).

We used the Assessing the Methodological Quality of Systematic Reviews (AMSTAR) $)^{10}$ checklist to assess whether each review met, for example, the following criteria: comprehensive search strategy involving 2 or more databases, explicit inclusion criteria, formal critical appraisal, and report the findings and direction of any pooled analyses. This checklist has been validated for assessing the quality of systematic reviews. ${ }^{11}$

\section{Outcomes}

The outcomes of this review were total combined symptommedication score, symptom score, medication score, diseasespecific quality of life and treatment adherence. We also assessed local or systemic reactions, anaphylaxis and death as reported in the included systematic reviews. Total combined symptom-medication score represents a measure intended to capture both symptom severity and medication use. This outcome is recommended by the World Allergy Organization as the favoured primary outcome for trials of allergen-specific immunotherapy in allergy, with changes in individual symptoms and/or quality of life as preferred secondary outcomes. ${ }^{12}$ We assessed all outcomes based on the definitions applied in the included systematic reviews.

\section{Synthesis}

The findings from reviews that reported pooled estimates of efficacy were grouped and synthesized with the use of a narrative approach. Narrative data are reported for harms data, including anaphylaxis (or use of epinephrine) and death. We 
also considered data separately for children and adults where available.

\section{Results}

\section{Literature search}

In total, 363 records were identified from the literature search (Figure 1). Of these, 44 records corresponding to 23 unique reviews met our inclusion criteria. Two of the 44 records corresponded to protocols for systematic reviews of allergen immunotherapy in allergic rhinoconjunctivitis and allergic asthma, ${ }^{13,14}$ and 1 systematic review compared the coadministration of SCIT and SLIT, ${ }^{15}$ which was beyond the scope of our review. The full list of included and excluded studies is available in Appendix 2 (available at www.cmajopen.ca/ content/5/2/E373/suppl/DC1.

\section{Review characteristics}

Of the 23 included reviews, 5 involved patients with a primary complaint of allergic asthma, and 18 involved patients with a primary complaint of allergic rhinitis (Table 1). Three of the 23 reviews included only children or adolescents, ${ }^{16,26,32}$ and the remainder included both adults and children; some of the reviews had subgroup analyses by age group. Four reviews involved only SCIT, 10 involved only SLIT, and 9 involved both SCIT and SLIT. The number of primary studies included in each review ranged from 4 to 267 , and the number of included allergens ranged from 1 to 9. Most of the reviews had poor compliance with the AMSTAR checklist (Appendix 3, available at www.cmajopen.ca/content/5/2/ E373/suppl/DC1): 3 reviews ${ }^{17,27,31}$ scored 11 points on the checklist, and the scores for the remaining reviews ranged from $0-10$ points. About one-third of the reviews (7/23 [30\%]) reported having an a priori research design. More than half $(13 / 23$ [56\%]) reported using duplicate reviewers for selection and/or data extraction, and two-thirds (15/23 [65\%]) reported a comprehensive literature search. Publication bias was assessed by 14 reviews $(61 \%)$.

\section{Benefits}

\section{Allergic asthma}

Five reviews assessed the benefits of allergen immunotherapy among patients with a primary complaint of allergic asthma $a^{1,16-19}$

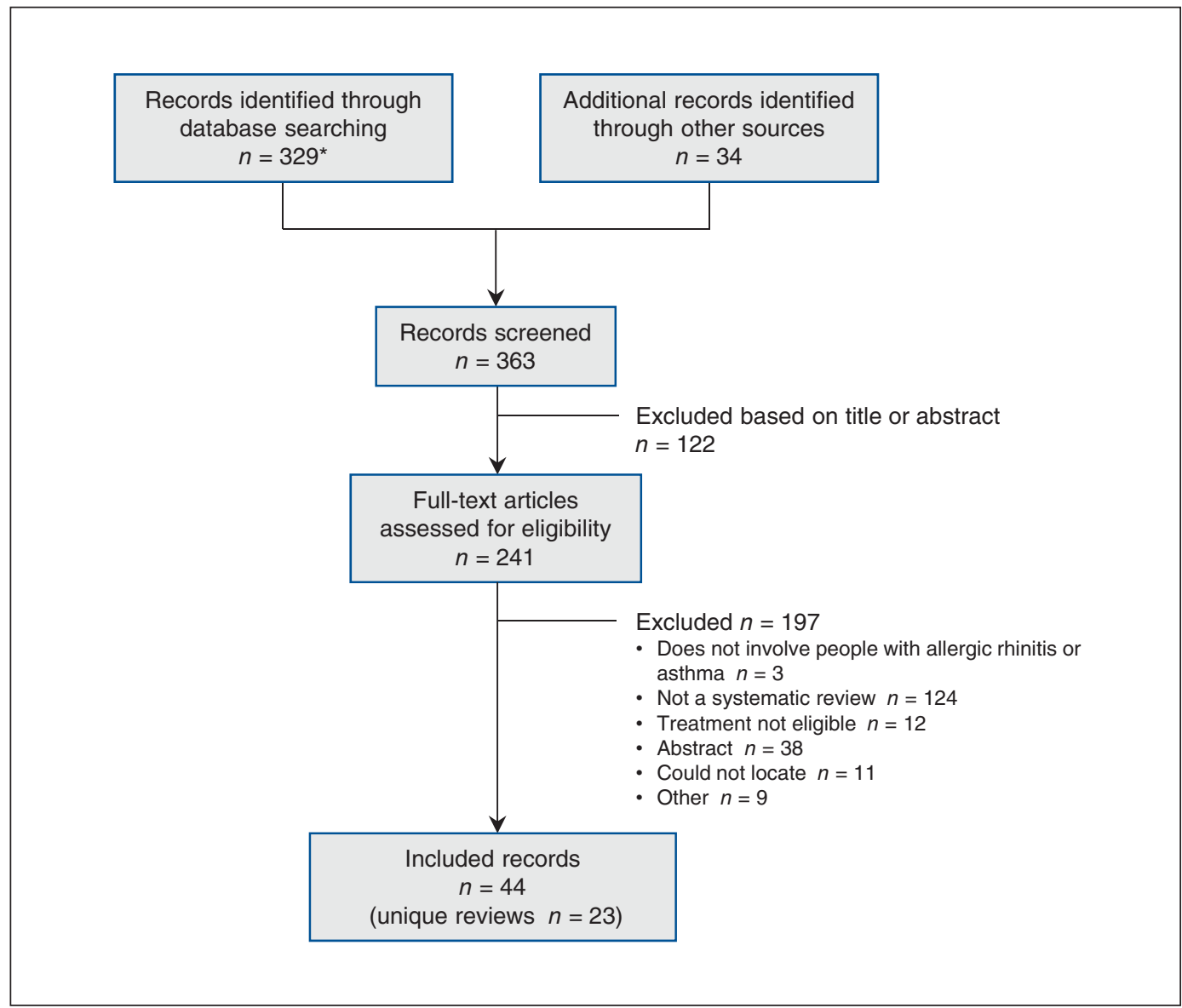

Figure 1: PRISMA (Preferred Reporting Items for Systematic Reviews and Meta-Analyses) diagram showing selection of included reviews. *The initial search results included studies on venom immunotherapy, which was subsequently determined to be outside the scope of this overview. Venom immunotherapy was assessed in the environmental scan portion of this drug class review (http://odprn.ca/wp-content/uploads/2016/02/AllergenImmunotherapy_Environmental-Report_Oct-2-2015_FINAL.pdf). 


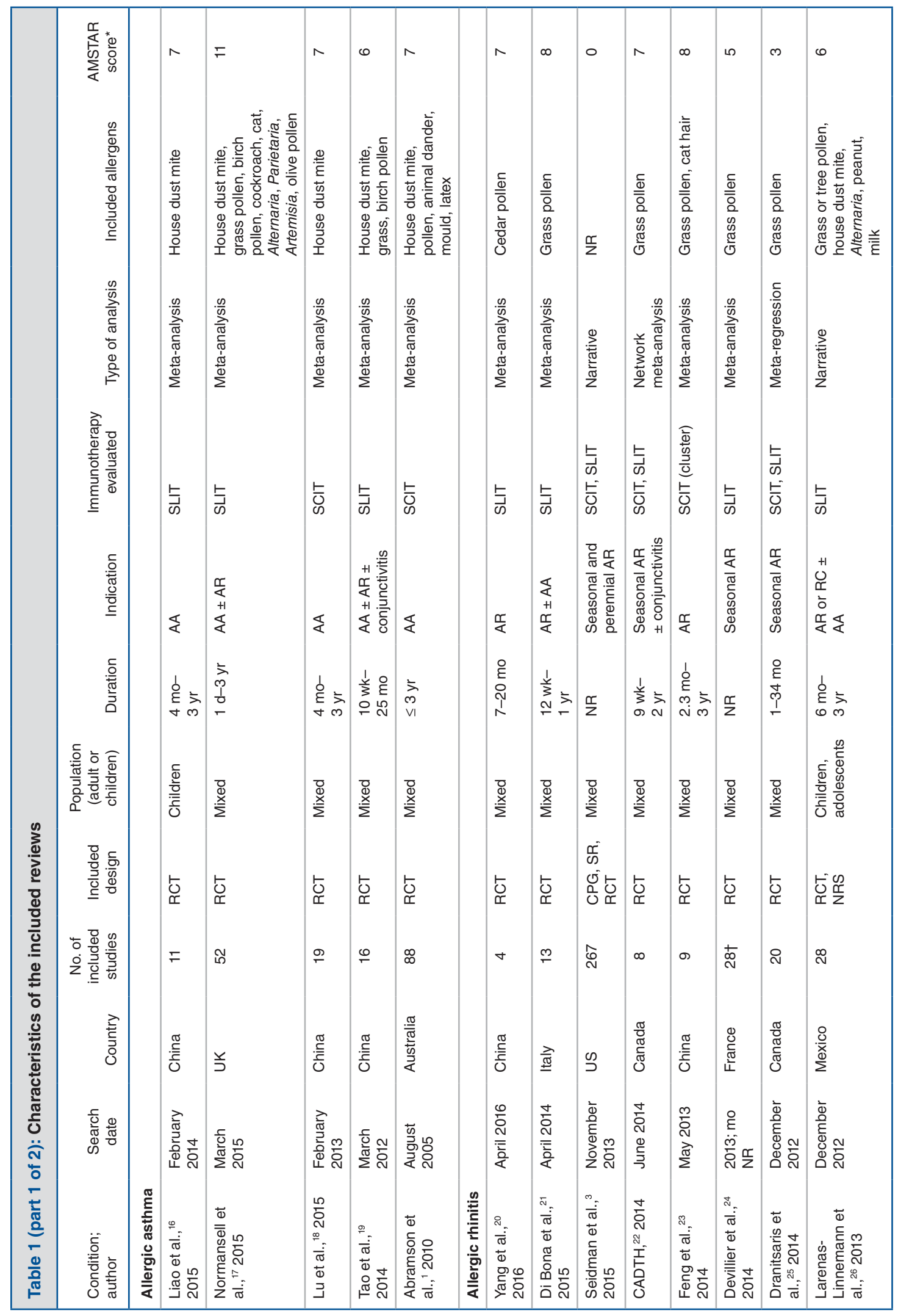




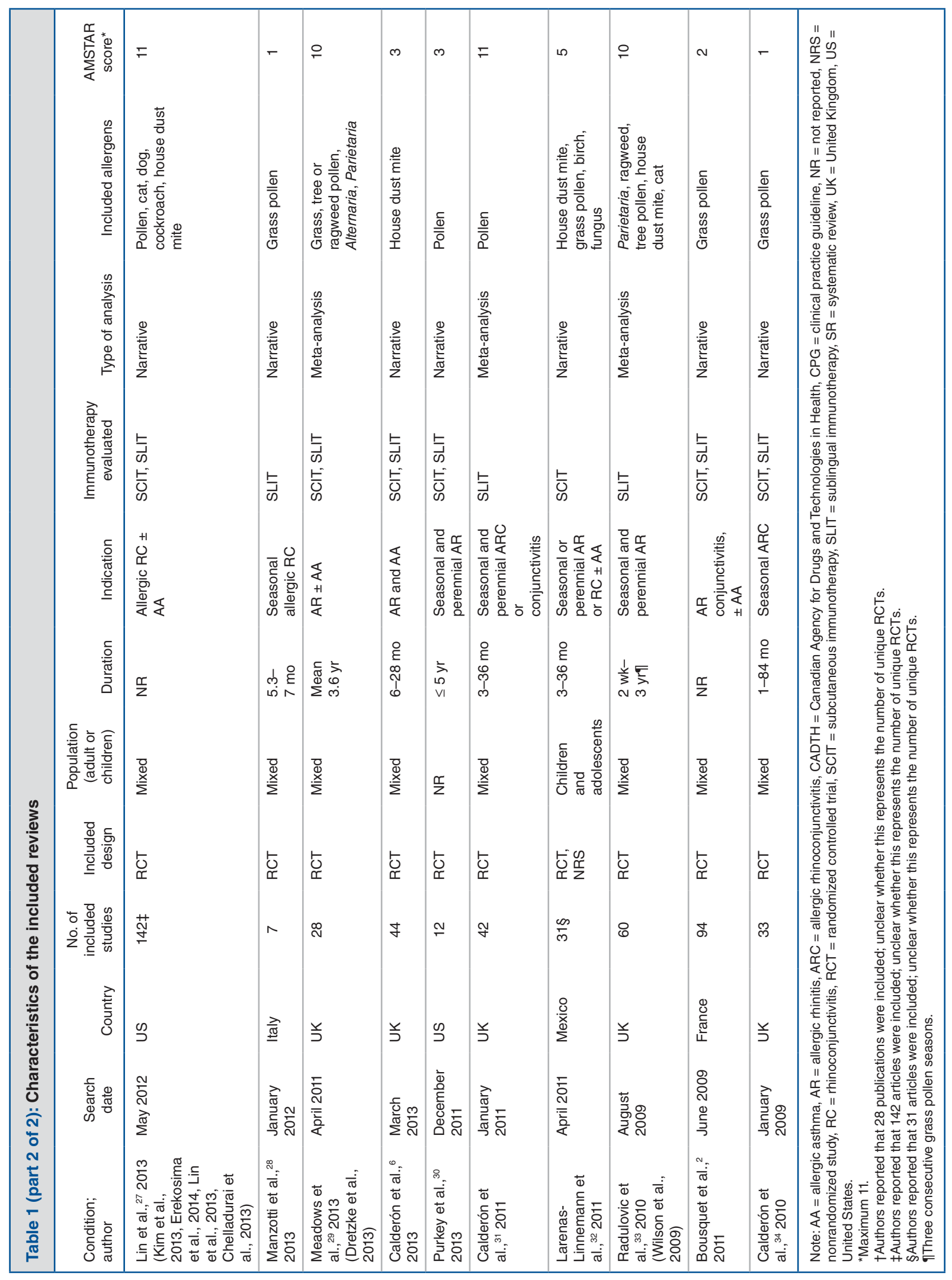


(Figure 2, Table 2). Four of the 5 reviews provided summary effect estimates for symptom score and/or medication score; none assessed total combined symptom-medication score, disease-specific quality of life or medication adherence. One review assessed asthma symptom score, medication score and quality of life among patients who received SLIT but did not provide an estimate of overall summary effect owing to methodological heterogeneity. ${ }^{17}$

Symptom score: Four reviews reported that participants receiving SCIT or SLIT had significantly improved symptom scores relative to placebo (standardized mean difference [SMD] range -1.02 to -0.59$) ;{ }^{1,16,18,19}$ however, the effect estimates were associated with high heterogeneity $\left(I^{2}=73 \%-\right.$ 92\%) (Table 2).

Medication score: Medication score was assessed in 2 reviews $^{16,19}$ (Table 2). One review reported significantly lower medication scores among participants receiving SLIT compared to placebo (SMD -0.78, 95\% confidence interval [CI -1.45 to -0.11$)^{19}$ (Table 2), and the other reported no statistically significant difference in medication score between groups (SMD $-0.52,95 \% \mathrm{CI}-1.75$ to 0.71 ). ${ }^{16}$ Both reviews reported high heterogeneity between trials for this outcome $\left(I^{2}=85 \%-93 \%\right)$.

\section{Allergic rhinitis}

Six reviews provided data comparing SLIT with placebo for an outcome of interest, ${ }^{20,21,24,25,29,33} 2$ provided data for SCIT versus placebo, ${ }^{25,29}$ and 2 provided data comparing SCIT and SLIT. ${ }^{25,29}$

Total combined symptom-medication score: Total combined symptom-medication scores were assessed in 3 reviews of SLIT and 1 review of SCIT ${ }^{20,24,29}$ (Figure 2, Table 3). The 3 reviews reported that SLIT significantly improved total combined symptom-medication score compared to placebo (SMD range -0.94 to -0.31 ). Each effect estimate was associated with moderate to high heterogeneity ( $I^{2}$ range $39 \%-$ $93 \%)$. In the review of SCIT, the authors reported a significant improvement in total combined symptom-medication score in the SCIT group (SMD $-0.48,95 \%$ CI -0.67 to $-0.29)$, with moderate heterogeneity $\left(I^{2}=22 \%\right){ }^{29}$

Symptom score: Three reviews reported a significant improvement in symptom score among patients taking SLIT compared to placebo (SMD range -0.49 to $-0.28 ; I^{2}=42 \%-$ $81 \%),{ }^{21,29,33}$ and 2 reviews reported improvements with SCIT compared to placebo (SMD range -0.65 to $-0.30 ; I^{2}=$ $57 \%)^{25,29}$

Two reviews compared the efficacy of SCIT versus SLIT via indirect treatment comparisons. ${ }^{25,29}$ Dranitsaris and Ellis ${ }^{25}$ reported a significant improvement in symptoms for SLIT relative to SCIT (SMD $-0.21,95 \% \mathrm{CI}-0.36$ to -0.07 ). In contrast, Meadows and colleagues ${ }^{29}$ reported a significant improvement in symptoms for SCIT relative to SLIT (standard score difference $0.35,95 \%$ credible interval 0.13 to 0.59 ).

Medication score: Three reviews reported significant improvement in medication scores among patients taking SLIT compared to placebo (SMD range -0.32 to -0.24 ), with moderate heterogeneity $\left(I^{2}=22 \%-50 \%\right)^{21,29,33}$ (Table 3). One review reported a significant improvement in medication score associated with SCIT compared to placebo (SMD $-0.55,95 \%$ CI -0.75 to $\left.-0.34 ; I^{2}=57 \%\right) .{ }^{29}$ Compared with SLIT, SCIT was associated with a significantly better response in terms of medication scores in 1 review (standard score difference $0.27,95 \%$ credible interval 0.03 to 0.53$)^{29}$ (Table 3).

Disease-specific quality of life: One review assessed diseasespecific quality of life, with a significant improvement reported for both SLIT (SMD -0.37, 95\% CI -0.52 to -0.22) and SCIT (mean difference $-0.74,95 \%$ CI -0.92 to -0.56 ) compared to placebo ${ }^{29}$ however, there was no significant difference between SLIT and SCIT via indirect treatment comparison (standard score difference $-0.52,95 \%$ credible interval -0.07 to 1.04 ) (Table 3 ).

Adherence: Adherence was not well reported. Dranitsaris and Ellis ${ }^{25}$ reported significantly increased treatment discontinuation for both SLIT and SCIT relative to placebo, with a reported relative risk for discontinuation of 1.90-4.88) (Table $3)$. Di Bona and colleagues ${ }^{21}$ also reported increased discontinuation among SLIT-treated patients $(6 \%)$ relative to patients in the control group $(2.2 \%)$.

\section{Harms}

Safety data were inconsistently reported, which made it difficult to summarize them. Poor reporting of safety outcomes in the primary randomized controlled trials was noted in some reviews. ${ }^{6,29}$ For SCIT, local reactions included swelling, itching and erythema. One review reported the relative risk of local reactions among SCIT-treated patients with asthma to be 1.96 (95\% CI 0.96 to 3.99 ) compared to placebo. ${ }^{18}$ Among patients with asthma treated with SCIT, the risk of a systemic adverse reaction was reported to be 2.45 (95\% CI 1.91 to 3.13). ${ }^{1}$ Local reactions among SLIT-treated patients included oral pruritus (39\% of patients treated with active SLIT), throat irritation (33\%), mild erythema (11\%), oral paraesthesia $(10 \%)$ and mouth edema $(9 \%){ }^{29}$

\section{Anaphylaxis}

Allergic asthma: Abramson and colleagues ${ }^{1}$ estimated the incidence of near-fatal reactions to be 1 per 1 million injections, with an increased relative risk of a systemic reaction (including anaphylaxis, asthma, rhinitis or urticaria) in the SCIT group (relative risk $2.45,95 \%$ CI 1.91 to 3.13 ) (Table 4). Calderón and colleagues ${ }^{6}$ reported the occurrence of serious adverse events, most of which occurred during rush updosing (an accelerated injection schedule) of SCIT.

Calderón and colleagues ${ }^{6}$ reported that 1 patient in the placebo group experienced severe exacerbation of asthma, and Tao and colleagues ${ }^{19}$ reported that 3 patients in the SLIT group of 1 trial experienced severe asthma.

Allergic rbinitis: Anaphylaxis or epinephrine use was reported in the SCIT group of 5 reviews ${ }^{6,27,29,30,34}$ (Table 4). One review reported the occurrence of anaphylaxis in a participant receiving placebo. ${ }^{29}$ Two reviews reported the occurrence of anaphylaxis among patients taking SLIT. ${ }^{22,28,29}$ Meadows and colleagues ${ }^{29}$ reported anaphylaxis in 2 trials, with 4 of 


\begin{tabular}{|c|c|c|c|}
\hline Comparison & Author & Allergen & Efficacy \\
\hline \multicolumn{4}{|l|}{ Allergic asthma } \\
\hline \multirow[t]{2}{*}{ SCIT v. placebo } & Lu et al., ${ }^{18} 2015$ & House dust mite & r \\
\hline & Abramson et al., ${ }^{1} 2010$ & $\begin{array}{l}\text { House dust mite, pollen, } \\
\text { animal dander, mould, } \\
\text { latex }\end{array}$ & s \\
\hline \multirow[t]{2}{*}{ SLIT v. placebo } & Liao et al., ${ }^{16} 2015$ & House dust mite & 000 \\
\hline & Tao et al.., ${ }^{19} 2014$ & $\begin{array}{l}\text { House dust mite, grass, } \\
\text { birch pollen }\end{array}$ & 00 \\
\hline \multicolumn{4}{|c|}{ Allergic rhinitis \pm rhinoconjunctivitis } \\
\hline \multirow[t]{2}{*}{ SCIT v. placebo } & Dranitsaris et al. ${ }^{25} 2014$ & Grass pollen & 00 \\
\hline & Meadows et al., ${ }^{29} 2013$ & $\begin{array}{l}\text { Grass, tree or ragweed } \\
\text { pollen, fungi, Parietaria }\end{array}$ & \\
\hline \multirow[t]{6}{*}{ SLIT v. placebo } & Yang et al., ${ }^{20} 2016$ & Cedar pollen & O \\
\hline & Di Bona et al., ${ }^{21} 2015$ & Grass pollen & 0 \\
\hline & Devillier et al.. ${ }^{24} 2014$ & Grass pollen & \\
\hline & Dranitsaris et al., ${ }^{25} 2014$ & Grass pollen & 00000 \\
\hline & Meadows et al., ${ }^{29} 2013$ & $\begin{array}{l}\text { Grass, tree or ragweed } \\
\text { pollen, fungi, Parietaria }\end{array}$ & 00000 \\
\hline & Radulovic et al., ${ }^{33} 2010$ & $\begin{array}{l}\text { Parietaria, ragweed, tree } \\
\text { pollen, house dust mite, } \\
\text { cat }\end{array}$ & 000 \\
\hline \multirow[t]{2}{*}{ SCIT v. SLIT } & Meadows et al., ${ }^{29} 2013$ & $\begin{array}{l}\text { Grass, tree or ragweed } \\
\text { pollen, fungi, Parietaria }\end{array}$ & 0000 \\
\hline & Dranitsaris et al. ${ }^{25} 2014$ & Grass pollen & 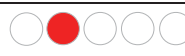 \\
\hline
\end{tabular}

Figure 2: Summary of benefits of subcutaneous (SCIT) and sublingual (SLIT) immunotherapy. The five contiguous circles correspond, respectively, to the 5 efficacy outcomes: total combined symptom-medication score, symptom score, medication score, disease-specific quality of life and adherence/discontinuation. A green circle indicates that immunotherapy is significantly better than placebo, a red circle indicates that immunotherapy is significantly worse than placebo, a grey circle indicates that there is no significant difference between immunotherapy and placebo, and a white circle indicates that the outcome was not available for analysis. In cases of immunotherapy versus immunotherapy, significance is reported relative to the first agent listed in the heading.

427 patients in the SLIT group experiencing anaphylaxis; there were no similar events in the placebo group $(n=282)$. Manzotti and colleagues ${ }^{28}$ reported that anaphylactic reactions had occurred in some patients given a maintenance dose of Grazax as their first dose; however, the number of patients affected was not reported. Di Bona and colleagues ${ }^{21}$ noted that no anaphylactic reactions occurred in the SLIT or placebo groups; however, 9 events that required epinephrine use were reported in the SLIT group, compared to 3 in the placebo group. One review reported epinephrine use in 1 patient in each of the placebo and SLIT groups. ${ }^{22}$

\section{Death}

Allergic asthma: No deaths were reported among patients treated with SCIT or SLIT; however, death was not included as an outcome in most reviews. Abramson and colleagues ${ }^{1}$ reported an estimated incidence of fatal reactions of 1 per 2.5 million SCIT injections.
Allergic rbinitis: No deaths were reported among SCITtreated patients. One review reported that reactions were rare but were associated with major morbidity/mortality when they occurred. ${ }^{30}$

No deaths were reported in 2 of 3 reviews that assessed SLIT. ${ }^{27,34}$ One review reported that 3 deaths occurred in 3 trials, all in the SLIT group; ${ }^{22}$ however, none were considered by the manufacturer to be related to treatment.

\section{Subgroups}

Adults

Benefits: One review assessed symptom and medication scores among adults with allergic asthma treated with SLIT and reported a significant improvement in symptom scores among participants taking SLIT compared to placebo, with no significant differences in medication scores ${ }^{19}$ (Appendix 4, available at www.cmajopen.ca/content/5/2/E373/suppl/DC1). No 


\begin{tabular}{|c|c|c|c|c|c|c|c|}
\hline \multirow[b]{2}{*}{ Author } & \multirow[b]{2}{*}{ Population } & \multirow[b]{2}{*}{ Included allergens } & \multirow[b]{2}{*}{ Comparison } & \multicolumn{2}{|c|}{$\begin{array}{l}\text { Unadjusted standard mean } \\
\text { difference }(95 \% \mathrm{Cl}) ; l^{2} ; \mathrm{k}\end{array}$} & \multirow[b]{2}{*}{$\begin{array}{l}\text { AMSTAR } \\
\text { score* }^{*}\end{array}$} & \multirow[b]{2}{*}{$\begin{array}{l}\text { Search } \\
\text { date }\end{array}$} \\
\hline & & & & Symptom score & $\begin{array}{l}\text { Medication } \\
\text { score }\end{array}$ & & \\
\hline $\begin{array}{l}\text { Liao et al.., }{ }^{16} \\
2015\end{array}$ & $\begin{array}{l}\text { Children with } \\
\text { AA }\end{array}$ & House dust mite & SLIT v. placebo & $\begin{array}{c}-1.02 \\
(-2.07 \text { to }-0.33) \\
92 \% ; 8\end{array}$ & $\begin{array}{c}-0.52 \\
(-1.75 \text { to } 0.71) \\
85 \% ; 3\end{array}$ & 7 & $\begin{array}{l}\text { February } \\
2014\end{array}$ \\
\hline $\begin{array}{l}\text { Normansell } \\
\text { et al., }{ }^{17} 2015\end{array}$ & $A A \pm A R$ & $\begin{array}{l}\text { House dust mite, } \\
\text { grass, pollen, birch } \\
\text { pollen, cockroach, } \\
\text { cat, Alternaria, } \\
\text { Parietaria, } \\
\text { Artemisia, olive } \\
\text { pollen }\end{array}$ & SLIT v. placebo & - & - & 11 & $\begin{array}{l}\text { March } \\
2015\end{array}$ \\
\hline $\begin{array}{l}\text { Lu et al., }{ }^{18} \\
2015\end{array}$ & AA & House dust mite & SCIT v. placebo & $\begin{array}{c}-0.94 \\
(-1.58 \text { to }-0.29) \\
92 \% ; 13\end{array}$ & - & 7 & $\begin{array}{l}\text { February } \\
2013\end{array}$ \\
\hline $\begin{array}{l}\text { Tao et al.. }{ }^{19} \\
2014\end{array}$ & $\begin{array}{l}\mathrm{AA} \pm \mathrm{AR} \\
\text { and/or } \\
\text { conjunctivitis }\end{array}$ & $\begin{array}{l}\text { House dust mite, } \\
\text { grass, birch pollen }\end{array}$ & SLIT v. placebo & $\begin{array}{c}-0.74 \\
(-1.26 \text { to }-0.22) \\
91 \% ; \mathrm{NR}\end{array}$ & $\begin{array}{c}-0.78 \\
(-1.45 \text { to }-0.11) \\
93 \% ; \mathrm{NR}\end{array}$ & 6 & $\begin{array}{l}\text { March } \\
2012\end{array}$ \\
\hline $\begin{array}{l}\text { Abramson et } \\
\text { al., }{ }^{1} 2010\end{array}$ & AA & $\begin{array}{l}\text { House dust mite, } \\
\text { pollen, dander, } \\
\text { mould, latex }\end{array}$ & SCIT v. placebo & $\begin{array}{c}-0.59 \\
(-0.83 \text { to }-0.35) \\
73 \% ; 34\end{array}$ & - & 7 & $\begin{array}{l}\text { August } \\
2005\end{array}$ \\
\hline
\end{tabular}

review reported the efficacy of SCIT among adults with allergic asthma.

Two reviews assessed the efficacy of SLIT among adults with allergic rhinitis. ${ }^{29,33}$ Meadows and colleagues ${ }^{29}$ reported a significant improvement in total combined symptom-medication score, symptom score, medication score and disease-specific quality of life for SLIT relative to placebo. Radulovic and colleagues $^{33}$ also reported a significant improvement in symptom scores in the SLIT group.

One review assessed the efficacy of SCIT among adults with allergic rhinitis and reported significantly improved symptom and medication scores among participants in the SLIT group relative to those in the placebo group ${ }^{29}$ (Appendix 5, available at www.cmajopen.ca/content/5/2/E373/ suppl/DC1).

Harms: No reviews assessed anaphylaxis or death among adults with allergic asthma or allergic rhinitis taking SCIT.

One review reported anaphylaxis in 5 participants receiving SLIT; there were no cases of anaphylaxis in the placebo group. ${ }^{22}$ Three deaths were reported among adults with allergic rhinitis taking SLIT.22

\section{Children}

Benefits: No reviews assessed the efficacy of SCIT in children with allergic asthma or allergic rhinitis. The efficacy of SLIT in children with allergic asthma was assessed in 2 reviews s.,19 $^{16}$ (Appendix 6, available at www.cmajopen.ca/content/5/2/
E373/suppl/DC1). Tao and colleagues ${ }^{19}$ and Liao and colleagues ${ }^{16}$ both reported significant improvements in symptom scores among children taking SLIT compared to placebo. Tao and colleagues ${ }^{19}$ reported a significant improvement in medication score among children receiving SLIT compared to placebo, whereas Liao and colleagues ${ }^{16}$ reported no significant differences for this comparison.

Two reviews reported significant improvements in symptom scores among children with allergic rhinitis taking SLIT compared to placebo; there were no significant betweengroup differences in medication score. ${ }^{29,33}$ Total combined symptom-medication score, disease-specific quality of life and treatment discontinuation were not assessed in children.

Harms: Anaphylaxis and death were not assessed among children with allergic asthma.

Among children with allergenic rhinitis, 3 reviews reported anaphylaxis or epinephrine use in the SLIT group ${ }^{22,29,32}$ (Appendix 7, available at www.cmajopen.ca/content/5/2/ E373/suppl/DC1. It is difficult to judge overlap between these reviews because of the use of confidential manufacturer's reports in 1 review. ${ }^{22}$ Most participants who required epinephrine were in the SLIT group. One study reported the occurrence of anaphylaxis in a child who received SCIT. ${ }^{27}$

No deaths were reported in either review that assessed deaths among children with allergic rhinitis treated with SLIT. ${ }^{22,27}$ One review assessed deaths among children with allergic rhinitis receiving SCIT: no deaths were reported. ${ }^{27}$ 


\section{Interpretation}

As part of a drug class review, we performed a rapid overview of systematic reviews to assess the benefits and harms of allergenspecific immunotherapy in patients with allergic asthma or rhinitis. In general, SCIT and SLIT were more effective than pla- cebo at reducing symptom scores, medication scores and total combined symptom-medication scores. SCIT may be more effective than SLIT at improving medication and symptom scores; however, this finding was based on limited evidence. Anaphylaxis and death were not consistently assessed, especially among children, but events were infrequent.

\section{Table 3: Benefits of subcutaneous and sublingual immunotherapy among participants with allergic rhinitis}

\begin{tabular}{|c|c|c|c|c|c|c|c|c|c|}
\hline \multirow[b]{2}{*}{$\begin{array}{l}\text { Comparison; } \\
\text { author }\end{array}$} & \multirow[b]{2}{*}{ Population } & \multirow[b]{2}{*}{ Allergen } & \multicolumn{5}{|c|}{ Unadjusted standard mean difference $\left(95 \% \mathrm{Cl}^{*}\right) ; l^{2} ; \mathrm{k}$} & \multirow[b]{2}{*}{$\begin{array}{l}\text { AMSTAR } \\
\text { score } \neq\end{array}$} & \multirow[b]{2}{*}{$\begin{array}{l}\text { Search } \\
\text { date }\end{array}$} \\
\hline & & & $\begin{array}{l}\text { Total combined } \\
\text { symptom- } \\
\text { medication score }\end{array}$ & Symptom score & Medication score & $\begin{array}{l}\text { Disease-specific } \\
\text { quality of life }\end{array}$ & $\begin{array}{c}\text { Treatment } \\
\text { discontinuation } †\end{array}$ & & \\
\hline \multicolumn{10}{|c|}{ SLIT v. placebo } \\
\hline $\begin{array}{l}\text { Yang et al., }{ }^{20} \\
2016\end{array}$ & & Cedar pollen & $\begin{array}{c}-0.94 \\
(-1.75 \text { to }-0.14) \\
93 \% ; 4\end{array}$ & - & - & - & - & 6 & April 2016 \\
\hline $\begin{array}{l}\text { Di Bona et } \\
\text { al., }{ }^{21} 2015\end{array}$ & ARC & Grass pollen & - & $\begin{array}{c}-0.28 \\
(-0.37 \text { to }-0.19) \\
54 \% ; 13\end{array}$ & $\begin{array}{c}-0.24 \\
(-0.31 \text { to }-0.17) \\
22 \% ; 12\end{array}$ & - & $\begin{array}{c}\text { SLIT: } 6 \% \text {, } \\
\text { placebo: } 2.2 \%\end{array}$ & 9 & April 2014 \\
\hline $\begin{array}{l}\text { Devillier et } \\
\text { al., }{ }^{24} 2014\end{array}$ & ARC & $\begin{array}{l}\text { Grass, tree or } \\
\text { ragweed pollen }\end{array}$ & $\begin{array}{c}\text { Hedges } g-0.31 \\
(-0.39 \text { to }-0.22) \\
\text { NR; } 11\end{array}$ & - & - & - & - & 5 & $2013 \S$ \\
\hline $\begin{array}{l}\text { Dranitsaris } \\
\text { et al. }{ }^{25} 2014 \\
\text { (Oralair) }\end{array}$ & & Grass pollen & - & - & - & - & $\begin{array}{c}\text { RR } 4.88 \\
\text { (2.41 to } 9.79) ; \\
6 \text { trial arms }\end{array}$ & 3 & $\begin{array}{l}\text { December } \\
2012\end{array}$ \\
\hline $\begin{array}{l}\text { Dranitsaris } \\
\text { et al., }{ }^{25} 2014 \\
\text { (Grazax) }\end{array}$ & & Grass pollen & - & - & - & - & $\begin{array}{c}\text { RR } 1.90 \\
(1.21 \text { to } 3.00) \\
8 \text { trial arms }\end{array}$ & 3 & $\begin{array}{l}\text { December } \\
2012\end{array}$ \\
\hline $\begin{array}{l}\text { Meadows et } \\
\text { al., }{ }^{29} 2013\end{array}$ & $\mathrm{AR} \pm \mathrm{AA}$ & $\begin{array}{l}\text { Grass, tree or } \\
\text { ragweed } \\
\text { pollen, } \\
\text { Alternaria, } \\
\text { Parietaria }\end{array}$ & $\begin{array}{c}-0.40 \\
(-0.55 \text { to }-0.25) \\
39 \% ; 6\end{array}$ & $\begin{array}{c}-0.33 \\
(-0.42 \text { to }-0.25) \\
42 \% ; 42\end{array}$ & $\begin{array}{c}-0.27 \\
(-0.37 \text { to }-0.17) \\
49 \% ; 35\end{array}$ & $\begin{array}{c}-0.37 \\
(-0.52 \text { to }-0.22) \\
59 \% ; 7\end{array}$ & - & 10 & April 2011 \\
\hline $\begin{array}{l}\text { Radulovic et } \\
\text { al., }{ }^{33} 2010\end{array}$ & AR & $\begin{array}{l}\text { Parietaria, tree } \\
\text { or ragweed } \\
\text { pollen, house } \\
\text { dust mite, cat }\end{array}$ & - & $\begin{array}{c}-0.49 \\
(-0.64 \text { to }-0.34) \\
81 \% ; 49\end{array}$ & $\begin{array}{c}-0.32 \\
(-0.43 \text { to }-0.21) \\
50 \% ; 38\end{array}$ & - & - & 10 & $\begin{array}{l}\text { August } \\
2009\end{array}$ \\
\hline \multicolumn{10}{|c|}{ SCIT v. placebo } \\
\hline $\begin{array}{l}\text { Dranitsaris } \\
\text { et al., }{ }^{25} \\
2014 \emptyset\end{array}$ & & Grass pollen & - & $\begin{array}{c}-0.30 \\
(-0.39 \text { to }-0.20) \\
7 \text { trial arms }\end{array}$ & - & - & $\begin{array}{c}\text { RR } 3.16 \\
\text { (1.40 to } 7.10) ; \\
7 \text { trial arms }\end{array}$ & 3 & $\begin{array}{l}\text { December } \\
2012\end{array}$ \\
\hline $\begin{array}{l}\text { Meadows et } \\
\text { al., }{ }^{29} 2013\end{array}$ & $\mathrm{AR} \pm \mathrm{AA}$ & $\begin{array}{l}\text { Grass, tree or } \\
\text { ragweed } \\
\text { pollen, } \\
\text { Alternaria, } \\
\text { Parietaria }\end{array}$ & $\begin{array}{c}-0.48 \\
(-0.67 \text { to }-0.29) \\
22 \% ; 8\end{array}$ & $\begin{array}{c}-0.65 \\
(-0.85 \text { to }-0.45) \\
57 \% ; 17\end{array}$ & $\begin{array}{c}-0.55 \\
(-0.75 \text { to }-0.34) \\
57 \% ; 16\end{array}$ & $\begin{array}{c}\mathrm{MD}-0.74 \\
(-0.92 \text { to }-0.56) \\
0 \% ; 8\end{array}$ & - & 10 & April 2011 \\
\hline \multicolumn{10}{|c|}{ SCIT v. SLITף } \\
\hline $\begin{array}{l}\text { Dranitsaris } \\
\text { et al., }{ }^{25} 2014\end{array}$ & & Grass pollen & - & $\begin{array}{c}-0.21 \\
(-0.36 \text { to }-0.07) \\
7 \text { trial arms; } \\
\text { favours SLIT }\end{array}$ & - & - & - & 3 & $\begin{array}{l}\text { December } \\
2012\end{array}$ \\
\hline $\begin{array}{l}\text { Meadows et } \\
\text { al. }{ }^{29} 2013\end{array}$ & $\mathrm{AR} \pm \mathrm{AA}$ & $\begin{array}{l}\text { Grass, tree or } \\
\text { ragweed } \\
\text { pollen, } \\
\text { Alternaria, } \\
\text { Parietaria }\end{array}$ & - & $\begin{array}{l}\text { SSD } 0.35 \\
\text { (0.13 to } 0.59) \\
\text { favours SCIT; } \\
\text { SCIT: } 17 \text { trials, } \\
\text { SLIT: } 42 \text { trials }\end{array}$ & $\begin{array}{c}\text { SSD } 0.27 \\
\text { (0.03 to } 0.53) \\
\text { favours SCIT; } \\
\text { SCIT: } 16 \text { trials, } \\
\text { SLIT: } 35 \text { trials }\end{array}$ & $\begin{array}{l}\text { SSD }-0.52 \\
(-0.07 \text { to } 1.04) \\
\text { SCIT: } 8 \text { trials, } \\
\text { SLIT: } 4 \text { trials }\end{array}$ & - & 10 & April 2011 \\
\hline $\begin{array}{l}\text { Note: } \mathrm{AA}=\text { all } \\
\text { trials, } \mathrm{RC}=\mathrm{rh} \\
{ }^{*} 95 \% \text { credible } \\
\text { †Treatment dis } \\
\text { †Maximum } 11 . \\
\text { §Month not re } \\
\text { ๆlndirect treat }\end{array}$ & $\begin{array}{l}\text { ergic asthma, } \\
\text { inoconjunctivi } \\
\text { interval for in } \\
\text { scontinuation, } \\
\text { ported. } \\
\text { ment compari }\end{array}$ & $\begin{array}{l}\mathrm{AR}=\text { allergic rhini } \\
\text { itis, } \mathrm{RR}=\text { relative } \\
\text { direct treatment } \mathrm{co} \\
\text {, not discontinuatio } \\
\text { isons. }\end{array}$ & $\begin{array}{l}\text { tis, } A R C=\text { allergic rh } \\
\text { isk, SCIT = subcutan } \\
\text { omparisons (SCIT v. } \\
\text { n owing to adverse }\end{array}$ & $\begin{array}{l}\text { inoconjunctivitis, MD } \\
\text { eous immunotherapy } \\
\text { SLIT). } \\
\text { vents. }\end{array}$ & $\begin{array}{l}\text { mean difference, N } \\
\text { SLIT = sublingual im }\end{array}$ & $\begin{array}{l}R=\text { not reported, } \mathrm{k}= \\
\text { Imunotherapy, } \mathrm{SSD}=\end{array}$ & $\begin{array}{l}=\text { number of include } \\
=\text { standardized sco }\end{array}$ & $\begin{array}{l}\text { randomized } \\
\text { difference. }\end{array}$ & \\
\hline
\end{tabular}




\section{OPEN}

Research

Table 4 (part 1 of 2): Anaphylaxis and death reported among participants ${ }^{\star}$

Condition;

author

Intervention

Anaphylaxis

Death

\section{Allergic asthma}

$\begin{array}{lll}\begin{array}{l}\text { Normansell } \\ \text { et al., }{ }^{17} 2015\end{array} & \text { SLIT v. placebo } & \text { NR } \\ \begin{array}{l}\text { Calderón et } \\ \text { al., }{ }^{6} 2013\end{array} & \text { SCIT v. placebo } & \begin{array}{l}\text { "Several serious TEAEs (some of which required epinephrine) } \\ \text { were reported. Pichler et al.(56) mentioned use but did not state } \\ \text { whether this concerned an active treatment or placebo group } \\ \text { participant. The } 4 \text { incidents reported by Bousquet et al.(25) (3 of } \\ \text { which required epinephrine) all concerned the active treatment } \\ \text { group during the rush updosing phase" }\end{array}\end{array}$

Lu et al., ${ }^{18} \quad$ SCIT v. placebo NR NR

2015

al., ${ }^{1} 2010$

Systemic reactions were defined as any of anaphylaxis, asthma, rhinitis or urticaria, or any combination of these. The pooled relative risk was $2.45(95 \% \mathrm{Cl} 1.91$ to 3.13$)$ in the 26 reporting reactions per patient and this was relatively homogeneous $\left(I^{2}=\right.$ $27 \%) . "$

Incidence of near-fatal reactions estimated to be 1 per 1 million reactions

Liao et al., ${ }^{16} \quad$ SLIT v. placebo NR NR

\begin{tabular}{|c|c|c|}
\hline $\begin{array}{l}\text { Calderón et } \\
\text { al., }{ }^{6} 2013\end{array}$ & SLIT v. placebo & $\begin{array}{l}\text { "The only serious adverse event }(\mathrm{AE}) \text { reported was a severe } \\
\text { exacerbation of asthma in } 1 \text { patient in the placebo group in th }\end{array}$ \\
\hline
\end{tabular}

al., ${ }^{6} 2013$ exacerbation of asthma in 1 patient in the placebo group in the study by Pham-Thi et al.(55)"

"None of the included studies reported any deaths."

NR

NR

Incidence of fatal reactions estimated to be 1 per 2.5 million

NR

"The only serious adverse event (AE) reported was a severe exacerbation of asthma in 1 patient in the placebo group in the study by Pham-Thi et al.(55)"

Tao et al., ${ }^{19} \quad$ SLIT v. placebo

"The main adverse reactions in our analysis were mild local NR

2014 reactions, such as mouth and/or throat itchiness, redness and swelling. The risk of adverse effects found in our meta-analysis was RR 2.23 (95\% Cl 1.17 to 4.24; p = 0.01) (Fig. 9). However, Tari et al. reported that severe asthma occurred in three patients attributing to the side effects of SLIT. (22)"

\section{Allergic rhinitis}

Calderón et SCIT v. placebo
al., ${ }^{34} 2010$

"All studies reported a higher proportion of adverse events (AEs) in NR SIT groups than in placebo groups. Systemic AEs requiring administration of subcutaneous adrenaline were observed. (17, 21)" Both were in SCIT group.

\begin{tabular}{|c|c|c|c|}
\hline $\begin{array}{l}\text { Calderón et } \\
\text { al., }{ }^{6} 2013\end{array}$ & SCIT v. placebo & $\begin{array}{l}\text { "The } 2 \text { earliest publications }(23,36) \text { each featured } 1 \text { anaphylactic } \\
\text { reaction caused by SCIT. More recent trials did not observe } \\
\text { anaphylactic reactions." }\end{array}$ & NR \\
\hline $\begin{array}{l}\text { Meadows et } \\
\text { al., }{ }^{29} 2013\end{array}$ & SCIT v. placebo & $\begin{array}{l}\text { "Post-injection anaphylaxis was reported in only one small trial } \\
\text { (159) (total } n=76 \text { ) but was considerably more frequent following } \\
\text { active treatment, occurring in approximately } 10 \text { of } 39 \text { patients } \\
\text { (compared with } 1 \text { of } 37 \text { receiving placebo); } 8 \text { of the } 10 \text { patients } \\
\text { were treated with adrenaline." }\end{array}$ & NR \\
\hline $\begin{array}{l}\text { Lin et al., }{ }^{27} \\
2013\end{array}$ & SCIT v. placebo & $\begin{array}{l}\text { "Thirteen anaphylactic reactions were reported in four trials." None } \\
\text { reported in control group. }\end{array}$ & "No deaths were reported." \\
\hline $\begin{array}{l}\text { Purkey et } \\
\text { al., }{ }^{30} 2013\end{array}$ & SCIT v. placebo & $\begin{array}{l}\text { "1 episode of anaphylaxis consisting of asthma and pruritus of the } \\
\text { ear canal and oropharynx that required administration of } \\
\text { epinephrine and oral corticosteroids." } \\
\text { "In the patient who experienced anaphylaxis, symptoms developed } \\
1 \text { minute after administration of the } 61 \text { st dose of treatment. } \\
\text { Administration of subcutaneous epinephrine, intravenous } \\
\text { methylprednisone, and nebulized salbutamol resulted in rapid } \\
\text { resolution of symptoms. SCIT was discontinued in this patient." }\end{array}$ & $\begin{array}{l}\text { "Local and systemic reactions } \\
\text { (rare but with significant } \\
\text { morbidity/mortality if they } \\
\text { occur)." }\end{array}$ \\
\hline
\end{tabular}


Table 4 (part 2 of 2): Anaphylaxis and death reported among participants*

Condition;

author

Intervention

Anaphylaxis

Death

Yang et al., ${ }^{20}$ SLIT v. placebo NR $\quad$ NR

2016

Di Bona et SLIT v. placebo

al., ${ }^{21} 2015$

No anaphylactic reactions reported in either SLIT or placebo groups. Nine events requiring epinephrine administration were reported in the SLIT group compared with 3 in the placebo group.

\begin{tabular}{ll}
\hline $\begin{array}{l}\text { Devillier et } \\
\text { al., }{ }^{24} 2014\end{array}$ & SLIT v. placebo \\
\hline $\begin{array}{l}\text { CADTH, }{ }^{22} \\
2014\end{array}$ & SLIT v. placebo \\
\end{tabular}

NR

NR

"In studies P05238, P05239, and P08067, it was mentioned that no participants experienced anaphylactic shock, and in studies GT-02, GT-07, GT-08, GT-12, and GT-14, there was no specific mention of anaphylactic shock. No incidence of anaphylaxis was reported in GT-02, GT-07, GT-08, and GT-12. In study P05238, one participant in the PPAE group received epinephrine due to an adverse event that occurred following the first administration of the study drug, and one placebo-treated patient used epinephrine in response to an anxiety attack, which the manufacturer stated was not an indicated (or medically appropriate) use for this medication."

"There were no deaths reported in studies GT-07, GT-02, GT-14, GT-12, and P05239. In studies GT-08, $\mathrm{P} 05238$, and P08067, one death was reported in each study ... none were considered by the manufacturer to be treatment related."

Calderón et SLIT v. placebo $\quad$ "Bahceciler et al.(22) did not observe any AEs of note with a $\quad$ NR
al., ${ }^{6} 2013$ maintenance dose of $8 \mathrm{mg}$ of 'Der p' allergens in children and adolescents. In contrast, de Bot et al.(31) studied a maintenance dose of $2 \mathrm{mg}$ of Der $\mathrm{p} 1$ allergen and reported that $96 \%$ of both active and placebo group patients experienced TEAEs (including a high proportion of nonlocal AEs). Nevertheless, no immunotherapy-dependent serious AEs were reported in any of the active groups."

\begin{tabular}{|c|c|c|c|}
\hline $\begin{array}{l}\text { Lin et al., }{ }^{27} \\
2013\end{array}$ & SLIT v. placebo & $\begin{array}{l}\text { "No life-threatening reactions, anaphylaxis, or deaths were } \\
\text { reported in these trials." }\end{array}$ & $\begin{array}{l}\text { "No life-threatening reactions, } \\
\text { anaphylaxis, or deaths were } \\
\text { reported in these trials." }\end{array}$ \\
\hline $\begin{array}{l}\text { Meadows et } \\
\text { al., }{ }^{29} 2013\end{array}$ & SLIT v. placebo & $\begin{array}{l}\text { "Anaphylaxis was reported in two trials }(192,195) \text { and occurred in } \\
4 \text { of } 427 \text { patients receiving active treatment and in none of } 282 \\
\text { patients receiving placebo." }\end{array}$ & NR \\
\hline $\begin{array}{l}\text { Manzotti et } \\
\text { al., }{ }^{28} 2013\end{array}$ & $\begin{array}{l}\text { SLIT } \\
\text { (Grazax or } \\
\text { Oralair) } \\
\text { v. placebo }\end{array}$ & $\begin{array}{l}\text { "However, it seems not advisable to use Grazax, that starts } \\
\text { directly with the maintenance dose, in subjects with an history of } \\
\text { systemic reactions to SCIT, because anaphylactic reactions at the } \\
\text { first dose were reported in such subjects. (21)" }\end{array}$ & NR \\
\hline $\begin{array}{l}\text { Radulovic et } \\
\text { al., }{ }^{33} 2010\end{array}$ & SLIT v. placebo & "None of the studies reported anaphylaxis." & NR \\
\hline $\begin{array}{l}\text { Calderón et } \\
\text { al., }{ }^{34} 2010\end{array}$ & $\begin{array}{l}\text { SLIT drops v. } \\
\text { placebo }\end{array}$ & "No life-threatening AEs or fatalities were described." & $\begin{array}{l}\text { "No life-threatening AEs or } \\
\text { fatalities were described." }\end{array}$ \\
\hline $\begin{array}{l}\text { Calderón et } \\
\text { al., }{ }^{34} 2010\end{array}$ & $\begin{array}{l}\text { SLIT tablets v. } \\
\text { placebo }\end{array}$ & $\begin{array}{l}\text { "All seven studies reported on safety in detail; the principal AEs } \\
\text { were mild, local and transient and none required adrenaline } \\
\text { administration. Treatment-related SAEs were not observed." }\end{array}$ & $\begin{array}{l}\text { "All seven studies reported on } \\
\text { safety in detail; the principal } \\
\text { AEs were mild, local and } \\
\text { transient and none required } \\
\text { adrenaline administration. } \\
\text { Treatment-related SAEs were } \\
\text { not observed." }\end{array}$ \\
\hline
\end{tabular}

Note: $\mathrm{AE}=$ adverse event, $\mathrm{CADTH}=\mathrm{Canadian}$ Agency for Drugs and Technologies in Health, $\mathrm{Cl}=$ confidence interval, NR $=$ not reported, $\mathrm{RR}=$ relative risk, $\mathrm{SAE}=$ systemic adverse event, SCIT = subcutaneous immunotherapy, SLIT = sublingual immunotherapy, TEAE = treatment-emergent adverse event *May include both children and adults.

In Canada, 3 SLIT products are commercially available (Oralair, Ragwitek and Grastek), whereas SCIT is typically compounded for patients based on their specific allergies (with the exception of Pollinex-R). Currently, Oralair and Ragwitek are available as limited use on the Ontario Drug Benefit for- mulary, and SCIT is available via the Ontario Drug Benefit Allergy Products program. Our overview was performed to provide decision-makers with information with which to update these listing criteria. As a result of this review, along with an environmental scan, a pharmacoepidemiologic study, a 
qualitative study and a pharmacoeconomic review, a series of recommendations were put forth to the Ontario Public Drug Programs to modernize the formulary listings (http://odprn. ca/wp-content/uploads/2015/10/Allergen-Immunotherapy_ Consolidated-Report_Oct-2-2015_FINAL.pdf).

An earlier overview that focused on the period 2003-2008 showed that allergen-specific immunotherapy was effective and safe for seasonal allergies. ${ }^{35}$ Our review is in agreement with this finding and adds more recent evidence supporting the efficacy and safety of allergen immunotherapy in patients with allergic rhinitis or asthma. The most recent Canadian guidelines recommend allergen immunotherapy for the treatment of allergic rhinitis or asthma caused by allergens for which clinical efficacy and safety have been shown. ${ }^{36}$

Recent German guidelines caution that, despite the welldocumented efficacy of allergen immunotherapy, high heterogeneity between trials renders generic recommendations difficult. ${ }^{37}$ Indeed, we found moderate to high heterogeneity for most outcomes, likely because of differences in included populations, allergens, and formulations of SCIT or SLIT. We found only 2 reviews that compared SCIT and SLIT via indirect treatment comparisons, with contradictory findings. These differences were likely due, at least in part, to differences in scope, dosing regimens and conduct.

\section{Limitations}

First, the use of rapid-review methodology is not without its limitations because there is a paucity of information detailing the impact of the methodological tailoring on the results or findings compared with more comprehensive systematic reviews. ${ }^{38}$ As well, the utility of a rapid review may be limited if the end-user does not have enough information to assess the strengths and weaknesses of the synthesis process and/or the results. ${ }^{39} \mathrm{We}$ performed a date- and language-limited review; however, we used the methodology guidelines of the Joanna Brigg Institute for the conduct of umbrella reviews ${ }^{7}$ to maintain rigorous standards for our review. Although we comprehensively searched within our defined timeframe, some relevant systematic reviews may not have been located or included. Given that systematic reviews may be out of date after a median of 5.5 years, ${ }^{40}$ we believe the impact to our results is likely minimal. As well, although we did not apply language restrictions during our literature search, we were unable to obtain translated versions of 11 publications during the review period. Thus, our findings are representative of the research published in English from 2010 to 2016.

Second, several of the included systematic reviews scored poorly on the AMSTAR checklist, which made it difficult to judge quality. Poor reporting also limited our capacity to assess the degree of overlap across the included systematic reviews. Third, of the included reviews, only 2 compared SLIT to SCIT. As such, we can comment primarily on the efficacy of SCIT or SLIT compared with placebo. Fourth, although we aimed to assess medication adherence, none of the included systematic reviews assessed adherence among patients with allergic asthma. Among patients with allergic rhinitis, 2 reviews reported that patients were more likely to discontinue SLIT or
SCIT compared to placebo. ${ }^{21,25}$ No data were available comparing discontinuation rates between SLIT and SCIT. Future reviews should consider using indirect treatment comparisons to provide information to decision-makers, clinicians and patients about the relative benefits and harms of each product.

\section{Conclusion}

This review provided decision-makers with a summary of the benefits and harms of allergen immunotherapy in patients with allergic asthma or allergic rhinitis as part of a formulary modernization project. The findings of our review suggest that both SCIT and SLIT are effective compared with placebo, but further work may be required to establish their comparative efficacy.

\section{References}

1. Abramson MJ, Puy RM, Weiner JM. Injection allergen immunotherapy for asthma. Cochrane Database Syst Rev 2010;8:CD001186.

2. Bousquet PJ, Calderón MA, Demoly P, et al. The Consolidated Standards of Reporting Trials (CONSORT) Statement applied to allergen-specific immunotherapy with inhalant allergens: a Global Allergy and Asthma European Network (GA(2)LEN) article. F Allergy Clin Immunol 2011;127:49-56, 56.e1-11.

3. Seidman MD, Gurgel RK, Lin SY, et al.; Guideline Otolaryngology Development Group. AAO-HNSF. Clinical practice guideline: allergic rhinitis. Otolaryngol Head Neck Surg 2015;152(Suppl):S1-43.

4. Cox L, Nelson H, Lockey R, et al. Allergen immunotherapy: a practice parameter third update. 7 Allergy Clin Immunol 2011;127:S1-55.

5. Nelson HS. Oral/sublingual Phleum pratense grass tablet (Grazax/Grastek) to treat allergic rhinitis in the USA. Expert Rev Clin Immunol 2014;10:1437-51.

6. Calderón MA, Casale TB, Nelson HS, et al. An evidence-based analysis of house dust mite allergen immunotherapy: a call for more rigorous clinical studies. 7 Allergy Clin Immunol 2013;132:1322-36.

7. The 7oanna Briggs Institute Reviewers' Manual 2014: methodology for 7BI mixed methods systematic reviews. Adelaide (Australia): Joanna Briggs Institute; 2014.

8. Kelly SE, Moher D, Clifford TJ. Defining rapid reviews: a modified Delphi consensus approach. Int 7 Technol Assess Health Care 2016;32:265-75.

9. Grey Matters Light. Ottawa: Canadian Agency for Drugs and Technologies in Health (CADTH); 2015. Available: https://www.cadth.ca/media/is/cadth_ Handout_greymatters_light_e.pdf (accessed 2016 May 11).

10. Shea BJ, Grimshaw JM, Wells GA, et al. Development of AMSTAR: a measurement tool to assess the methodological quality of systematic reviews. BMC Med Res Methodol 2007;7:10.

11. Shea BJ, Hamel C, Wells GA, et al. AMSTAR is a reliable and valid measurement tool to assess the methodological quality of systematic reviews. 7 Clin Epidemiol 2009;62:1013-20.

12. Canonica GW, Baena-Cagnani CE, Bousquet J, et al. Recommendations for standardization of clinical trials with allergen specific immunotherapy for respiratory allergy. A statement of a World Allergy Organization (WAO) taskforce. Allergy 2007;62:317-24.

13. Dhami S, Nurmatov U, Agache I, et al. Allergen immunotherapy for allergic asthma: protocol for a systematic review. Clin Transl Allergy 2016;6:5.

14. Dhami S, Nurmatov U, Roberts G, et al. Allergen immunotherapy for allergic rhinoconjunctivitis: protocol for a systematic review. Clin Transl Allergy 2016;6:12.

15. Creticos PS, Bernstein DI, Casale TB, et al. Coseasonal initiation of allergen immunotherapy: a systematic review. 7 Allergy Clin Immunol Pract 2016; 4: 1194-1204.e4.

16. Liao $\mathrm{W}, \mathrm{Hu} \mathrm{Q}$, Shen LL, et al. Sublingual immunotherapy for asthmatic children sensitized to house dust mite: a meta-analysis. Medicine (Baltimore) 2015;94:e701

17. Normansell R, Kew KM, Bridgman AL. Sublingual immunotherapy for asthma. Cochrane Database Syst Rev 2015;8:CD011293.

18. Lu Y, Xu L, Xia M, et al. The efficacy and safety of subcutaneous immunotherapy in mite-sensitized subjects with asthma: a meta-analysis. Respir Care 2015;60:269-78.

19. Tao L, Shi B, Shi G, et al. Efficacy of sublingual immunotherapy for allergic asthma: retrospective meta-analysis of randomized, double-blind and placebo-controlled trials. Clin Respir 7 2014;8:192-205.

20. Yang Y, Zhou W, Chen A. Efficacy of sublingual immunotherapy for cedar pollinosis: a systematic review and meta-analysis. Ann Allergy Astbma Immunol 2016;117:348-53.

21. Di Bona D, Plaia A, Leto-Barone MS, et al. Efficacy of grass pollen allergen sublingual immunotherapy tablets for seasonal allergic rhinoconjunctivitis: a systematic review and meta-analysis. FAMA Intern Med 2015;175:1301-9. 
22. Timothy grass standardized allergenic extract (Grastek - Merck Canada Inc.) indication: allergic rbinitis (grass pollen). Ottawa: Canadian Agency for Drugs and Technologies in Health (CADTH); 2014.

23. Feng $\mathrm{S}, \mathrm{Xu} \mathrm{Y}, \mathrm{Ma} \mathrm{R}$, et al. Cluster subcutaneous allergen specific immunotherapy for the treatment of allergic rhinitis: a systematic review and metaanalysis. PLoS One 2014;9:e86529.

24. Devillier P, Dreyfus JF, Demoly P, et al. A meta-analysis of sublingual allergen immunotherapy and pharmacotherapy in pollen-induced seasonal allergic rhinoconjunctivitis. BMC Med 2014;12:71.

25. Dranitsaris G, Ellis AK. Sublingual or subcutaneous immunotherapy for seasonal allergic rhinitis: an indirect analysis of efficacy, safety and cost. 7 Eval Clin Pract 2014;20:225-38

26. Larenas-Linnemann D, Blaiss M, Van Bever HP, et al. Pediatric sublingual immunotherapy efficacy: evidence analysis, 2009-2012. Ann Allergy Asthma Immunol 2013;110:402-15.e9.

27. Lin SY, Erekosima N, Suarez-Cuervo C, et al. Allergen-specific immunotherapy for the treatment of allergic rhinoconjunctivitis and/or asthma: comparative effectiveness review. Rockville (MD): Agency for Healthcare Research and Quality; 2013.

28. Manzotti G, Lombardi C. Allergen immunotherapy as a drug: the new deal of grass allergen tablets from clinical trials to current practice. Eur Ann Allergy Clin Immunol 2013;45:34-42.

29. Meadows A, Kaambwa B, Novielli N, et al. A systematic review and economic evaluation of subcutaneous and sublingual allergen immunotherapy in adults and children with seasonal allergic rhinitis. Health Technol Assess 2013; 17:vi, ix-xiv, 1-322.

30. Purkey MT, Smith TL, Ferguson BJ, et al. Subcutaneous immunotherapy for allergic rhinitis: an evidence based review of the recent literature with recommendations. Int Forum Allergy Rhinol 2013;3:519-31.

31. Calderón MA, Penagos M, Sheikh A, et al. Sublingual immunotherapy for treating allergic conjunctivitis. Cochrane Database Syst Rev 2011;7:CD007685.

32. Larenas-Linnemann DE, Pietropaolo-Cienfuegos DR, Calderón MA. Evidence of effect of subcutaneous immunotherapy in children: complete and updated review from 2006 onward. Ann Allergy Astbma Immunol 2011;107: 407-16.e11.

33. Radulovic S, Calderón MA, Wilson D, et al. Sublingual immunotherapy for allergic rhinitis. Cochrane Database Syst Rev 2010;12:CD002893.

34. Calderón M, Mösges R, Hellmich $M$, et al. Towards evidence-based medicine in specific grass pollen immunotherapy. Allergy 2010;65:420-34.

35. Hagen A, Gorenoi V, Schonermark MP. Specific immunotherapy (SIT) in the treatment of allergic rhinitis. GMS Health Technol Assess 2010;6:Doc01.

36. Leith E, Bowen T, Butchey J, et al. Consensus Guidelines on Practical Issues of Immunotherapy - Canadian Society of Allergy and Clinical Immunology (CSACI). Allergy Asthma Clin Immunol 2006;2:47-61.

37. Pfaar O, Bachert $\mathrm{C}$, Bufe A, et al. Guideline on allergen-specific immunotherapy in IgE-mediated allergic diseases: S2k Guideline of the German Society for Allergology and Clinical Immunology (DGAKI), the Society for Pediatric Allergy and Environmental Medicine (GPA), the Medical Association of German Allergologists (AeDA), the Austrian Society for Allergy and Immunology (OGAI), the Swiss Society for Allergy and Immunology (SGAI), the German Society of Dermatology (DDG), the German Society of OtoRhino-Laryngology, Head and Neck Surgery (DGHNO-KHC), the German Society of Pediatrics and Adolescent Medicine (DGKJ), the Society for Pediatric Pneumology (GPP), the German Respiratory Society (DGP), the German Association of ENT Surgeons (BV-HNO), the Professional Federation of Paediatricians and Youth Doctors (BVKJ), the Federal Association of Pulmonologists (BDP) and the German Dermatologists Association (BVDD). Allergo f Int 2014;23:282-319.

38. Tricco AC, Antony J, Zarin W, et al. A scoping review of rapid review methods. BMC Med 2015;13:224

39. Kelly SE, Moher D, Clifford TJ. Quality of conduct and reporting in rapid reviews: an exploration of compliance with PRISMA and AMSTAR guidelines. Syst Rev 2016;5:79.

40. Shojania KG, Sampson M, Ansari MT, et al. How quickly do systematic reviews go out of date? A survival analysis. Ann Intern Med 2007;147:224-33.

Affiliations: School of Epidemiology, Public Health and Preventive Medicine (Elliott, Kelly, Wells), University of Ottawa; Cardiovascular Research Methods Centre (Elliott, Kelly, Johnston, Wells), University of Ottawa Heart Institute; Li Ka Shing Knowledge Institute (Gomes), St. Michael's Hospital, Toronto, Ont. Becky Skidmore is an independent contractor in Ottawa, Ont.

Contributors: Jesse Elliott, Shannon Kelly, Tara Gomes and George Wells designed the study. Becky Skidmore developed and executed the search strategy. Jesse Elliott, Shannon Kelly and Amy Johnston selected studies for inclusion and extracted data. Jesse Elliott, Shannon Kelly, Amy Johnston and George Wells interpreted the data. Jesse Elliott wrote the first draft of the manuscript. All of the authors critically revised the manuscript for important intellectual content, approved the final version to be published and agreed to act as guarantors of the work.

Funding: This research was supported by the Ontario Drug Policy Research Network, which is funded by a grant from the Ontario Ministry of Health and Long-Term Care Health System Research Fund.

Acknowledgements: The authors thank Joshua Kofsky and Zemin Bai for assistance during the study selection and data extraction phases of this review.

Disclaimer: George Wells is a biostatistical consultant for CMA7 Open and was not involved in the editorial decision-making process for this article.

Supplemental information: For reviewer comments and the original submission of this manuscript, please see www.cmajopen.ca/content/5/27 E373/suppl/DC1 